Original Research

\title{
Kefir Susu Nabati dengan Penambahan Kulit Pisang Tanduk (Musa Paradisiacal Var. Corniculata)
}

\author{
Vina Priscilla ${ }^{1 *}$, Tjandra Pantjajani ${ }^{1}$, Fenny Irawati ${ }^{1}$ \\ ${ }^{1}$ Fakultas Teknobiologi, Universitas Surabaya, Raya Kalirungkut Surabaya-Indonesia 60293 \\ *corresponding author: vinapriscilla@gmail.com
}

\begin{abstract}
Non dairy milk contains high protein and carbohydrate, low fat, and free lactose. Even more, banana peel has a potential as prebiotic because it contains 33\% fructooligosaccharides (FOS). Banana peel was usually being thrown away although it still had good content. That would be a potential resource to make a non dairy kefir from it. This research aimed to know the effect on changes of fermentation parameters, the results of organoleptic tests, and the best treatment in making non dairy kefir with addition of Tanduk banana peel. The results showed that the parameters of total sugar, lactic acid, pH, TAT, viscosity, ethanol, number of yeast and $L A B$ tests were significantly different in each sample even though not all samples were significantly different on reducing sugar. The results of organoleptic tests showed that non dairy kefir without the addition of Tanduk banana peel was the most preferred kefir with quite sweet and sour taste, not alcoholic, less sour and quite unpleasant aroma, a yellowish white color, quite thick consistency, and not bitter aftertaste. The best treatment based on the effective-index method was non dairy kefir with the addition of $5 \%$ Tanduk banana peel.
\end{abstract}

Keywords: kefir, tanduk banana, non dairy milk

\begin{abstract}
Abstrak-Susu nabati memiliki kandungan protein dan karbohidrat yang tinggi, rendah lemak, serta tidak mengandung laktosa. Kulit pisang berpotensi sebagai prebiotik karena mengandung $33 \%$ fructooligosaccharides (FOS). Kandungan gizi kulit pisang dan susu nabati yang baik serta keinginan memanfaatkan kulit pisang Tanduk yang biasanya dibuang menjadi alasan untuk membuat kefir susu nabati dengan penambahan kulit pisang Tanduk. Tujuan penelitian ini adalah mengetahui pengaruh perubahan parameter fermentasi, hasil uji organoleptik, dan perlakuan terbaik dalam pembuatan kefir susu nabati dengan penambahan kulit pisang Tanduk. Penelitian ini mengunakan metode rancangan acak lengkap dengan variasi kadar kulit pisang Tanduk yang ditambahkan $0 \%, 5 \%$, dan $10 \%$. Hasil penelitian menunjukkan bahwa parameter gula total, asam laktat, pH, TAT, viskositas, etanol, jumlah khamir dan BAL, terdapat perbedaan signifikan pada setiap sampel, sedangkan pada parameter gula reduksi tidak semua sampel mengalami perbedaan signifikan. Hasil uji organoleptik kefir susu nabati tanpa penambahan kulit pisang Tanduk merupakan kefir yang paling disukai dengan karakteristik rasa yang cukup manis, cukup asam, tidak beralkohol, aroma kurang asam dan cukup langu, berwarna putih kekuningan, menghasilkan aftertaste yang tidak pahit, serta memiliki konsistensi cukup kental. Perlakuan terbaik berdasarkan metode indeks efektivitas adalah kefir susu nabati dengan penambahan kulit pisang Tanduk $5 \%$.
\end{abstract}

Kata kunci: kefir, pisang tanduk, susu nabati

\section{PENDAHULUAN}

Kefir, baik milk kefir atau water kefir, merupakan salah satu produk pangan fungsional alami, tetapi di Indonesia belum banyak dikembangkan. Milk kefir merupakan salah satu produk susu fermentasi. Kacang hijau dapat dijadikan

bahan susu nabati yang memiliki kandungan protein dan karbohidrat yang tinggi, tidak mengandung laktosa serta rendah lemak sehingga aman dikonsumsi oleh orang yang memiliki masalah kelebihan berat badan dan/atau hiperkolesterolemia (Robinson \& Singh, 2001). Kacang hijau yang digunakan adalah kacang hijau kupas (tanpa kulit) sehingga lebih hemat waktu dalam perendaman dan warna susu yang dihasilkan seperti warna susu pada umumnya.

Indonesia merupakan negara agraris, hampir seluruh wilayah Indonesia menghasilkan tanaman pisang (Musa spp.). Total produksi pisang di wilayah Jawa Timur mencapai 1.865.772 ton per tahun (BPS, 2016). Buah pisang banyak disukai untuk dikonsumsi, terutama Pisang Tanduk yang biasa digunakan untuk membuat pisang goreng oleh penjual gorengan karena harganya yang tergolong murah dan rasanya enak. Pisang menghasilkan limbah kulit pisang sebesar 30 - 40 g per 100 g berat pisang (Wachirasiri, Julakarangka, \& Wanlapa, 2009). Kulit 
pisang berpotensi sebagai prebiotik karena mengandung 33\% fructooligosaccharides (FOS) (Kurtoğlu \& Yildiz, 2011). FOS merupakan prebiotik yang terdiri dari polimer fruktosa yang digunakan secara komersial dalam produk makanan dan suplemen gizi (Barrangou, Altermann, Hutkins, Cano, \& Klaenhammer, 2003).

Selain itu dengan adanya penambahan kulit pisang Tanduk ini diharapkan dapat meningkatkan kandungan gizi pada susu kacang hijau dan kadar protein SNI susu fermentasi, yaitu minimal sebesar $2,7 \%$. Jika kadar protein tidak mencapai $2,7 \%$ maka susu bubuk kedelai akan ditambahkan karena kedelai memiliki kadar protein tinggi dan termasuk bahan nabati yang tidak mengandung laktosa (Fratiwi \& Noverita, 2008). Pengolahan susu nabati menjadi kefir diharapkan menjadi salah satu alternatif minuman kesehatan yang perlu tersedia di pasaran sehingga dapat menjadi pilihan minuman kesehatan bagi masyarakat yang mengalami lactose intolerance. Kandungan gizi dari susu berbahan nabati dan kulit pisang yang baik untuk tubuh menjadi alasan untuk membuat minuman probiotik dengan cara difermentasi menjadi minuman kefir susu nabati dengan penambahan kulit pisang Tanduk (Musa paradisiaca Var. Corniculata). Oleh karena itu, dengan memanfaatkan kulit pisang yang biasanya dibuang dapat meningkatkan nilai tambah bagi kulit pisang sekaligus mendapatkan prebiotik dengan harga yang murah. Tujuan dari penelitian ini adalah mengetahui pengaruh terhadap perubahan parameter fermentasi, hasil organoleptik, dan perlakuan terbaik dari kefir susu nabati dengan penambahan kulit pisang Tanduk.

\section{METODE}

Alat

Alat-alat yang akan digunakan dalam penelitian ini adalah inkubator (YIH DER LM595D), spektrofotometer (Genesys 105 UV-Vis), kuvet plastik, centrifuge (Hettich Zentrifugen Universal 320R), timbangan analitik (Adventure OHAUS), waterbath (Hol E4 HH-4), kulkas (SHARP), pH meter (Eutech Instrument), blender (Philips), kompor (Maspion), panci, kain saring, pengaduk, gelas kimia 50-2000 mL, buret, cawan petri, jarum ose, erlenmeyer 100-2000 $\mathrm{mL}$ (Pyrex), labu ukur 50-100 mL (Pyrex), gelas ukur 10-100 mL (Pyrex), pipet ukur $10 \mathrm{~mL}$, mikropipet 100-1000 $\mu \mathrm{l}$ (BioRad), sendok besi, hotplate stirrer, corong, statif, klem, viscometer (Rion), dan autoklaf.

\section{Bahan}

Bahan-bahan yang digunakan dalam penelitian ini adalah water kefir grains yang diperoleh dari Laboratorium Bionutrisi dan Inovasi Pangan Fakultas Teknobiologi Universitas Surabaya, kacang hijau kupas yang diperoleh di Toko Arvian Surabaya, pisang Tanduk (indeks warna no. 7) yang diperoleh di pasar Soponyono Rungkut Surabaya, gula pasir (Gulaku), reagen DNS (Merck), Rochelle's salt (Merck), akuades, spiritus, etanol 70\%, asam laktat (Merck), TCA (Merck), $\mathrm{H}_{2} \mathrm{SO}_{4}$ pekat (Mallinkcordt), $\mathrm{NaOH}$, indikator PP 1\%, CuSO ${ }_{4}$ (Merck), reagen PHF (Merck), fenol (Merck), Asam oksalat (Merck), media HE Agar (Merck), media Lactose Broth, media Bismulth Sulfite Agar (Merck), media Xylose Lysine Deoxycholate (Merck), media Brilliant Green Lactose Bile (Merck), dan aluminium foil (Reynold Wrap Heavy Duty).

\section{Variabel dan Parameter Penelitian}

Variabel dalam penelitian ini adalah variasi kulit pisang Tanduk matang bagian dalam (0\%, 5\%, dan $10 \%)$. Parameter yang diukur dalam penelitian ini adalah kadar etanol, asam laktat, gula reduksi, Total Asam Tertitrasi (TAT), pH, gula total, viskositas, jumlah BAL, khamir, kandungan nutrisi (lemak dan protein), organoleptik (rasa, warna, aroma, konsistensi, dan aftertaste), dan mikroba kontaminan.

\section{Pembuatan Kefir Susu Nabati dengan Penambahan Kulit Pisang Tanduk}

Kacang hijau disortir, dicuci, kemudian direndam dalam air \pm 1 jam. Setelah itu, kacang hijau direbus selama 10 menit lalu diblender dan disaring dengan kain saring. Komposisi 
penambahan air: kacang adalah 8:1. Kulit pisang yang digunakan adalah bagian dalam yang berwarna putih dari kulit pisang Tanduk matang (indeks warna no. 7) yang direndam dalam vitamin C 0,5\% (b/v) selama 10 menit untuk menjaga kulit tetap berwarna kuning dan tidak mengalami pencokelatan (Anyasi et al., 2014), lalu ditambahkan ke dalam susu kacang hijau lalu diblender. Setelah itu, campuran tersebut ditambah susu bubuk kedelai $15 \%$ (b/v) dan gula pasir $10 \%$ (b/v). Susu kacang hijau yang telah ditambah berbagai variasi kulit pisang Tanduk tersebut, masing-masing dipasteurisasi selama 30 menit pada suhu $65^{\circ} \mathrm{C}$, kemudian didinginkan pada suhu ruang. Setelah itu, susu tersebut ditambahkan dengan $10 \%(\mathrm{~b} / \mathrm{v}) \mathrm{kefir}$ starter. Proses inkubasi dilakukan pada suhu ruang selama 15 jam.

\section{Analisa Data}

Penelitian yang dilakukan merupakan penelitian eksperimental di laboratorium dengan rancangan acak lengkap. Data yang diperoleh dari hasil penelitian dianalisis menggunakan program Minitab. Dalam penelitian ini terdapat 2 jenis data, yaitu data parametrik dan data non-parametrik. Data parametrik diolah dengan metode ANOVA one way jika data berdistribusi normal dan homogen. Jika hasil statistik menunjukkan perbedaan signifikan dengan $\alpha=0,05$, maka dilakukan analisis multiple comparison dengan uji Tukey, sedangkan data non-parametrik pada uji organoleptik diuji dengan metode Kruskal-Wallis. Penentuan perlakuan terbaik dari semua parameter yang diukur dilakukan uji Indeks Efektivitas (DeGarmo, Sullivan, \& Canada, 1984). Peneliti menentukan bobot variabel uji kimia (protein, lemak, dan total asam) dan mikrobiologi (total bakteri starter dan khamir) berdasarkan standar SNI dan Codex sebesar $40 \%$ sedangkan uji organoleptik terhadap 30 panelis agak terlatih (rasa, warna, aroma, konsistensi, aftertaste) sebesar $60 \%$. Bobot normal untuk uji mikrobiologi dan kimia masing-masing sebesar 0,08 sedangkan untuk uji organoleptik dalam aspek rasa, warna, aroma, konsistensi, aftertaste berturut-turut sebesar 0,$13 ; 0,15 ; 0,12 ; 0,1 ;$ dan 0,1 .

\section{HASIL DAN BAHASAN}

\section{Hasil Uji Perubahan Karateristik Pada Kefir Susu NabatiDengan Penambahan Kulit Pisang Tanduk}

Tabel 1

Data Hasil Perubahan ( $\Delta$ ) Uji Karakteristik Kefir Susu Nabati dengan Penambahan Kulit Pisang Tanduk

\begin{tabular}{cccc}
\hline \multirow{2}{*}{ Parameter } & \multicolumn{3}{c}{ Kadar Kulit Pisang Tanduk (\%) } \\
\cline { 2 - 4 } & $\mathbf{0}$ & $\mathbf{5}$ & $\mathbf{1 0}$ \\
\hline Gula reduksi (\%) & $0,677^{\mathrm{b}} \pm 0,163$ & $0,770^{\mathrm{b}} \pm 0,140$ & $1,337^{\mathrm{a}} \pm 0,117$ \\
Gula total (\%) & $5,975^{\mathrm{c}} \pm 0,082$ & $8,225^{\mathrm{b}} \pm 0,463$ & $10,536^{\mathrm{a}} \pm 0,521$ \\
Asam laktat (\%) & $0,252^{\mathrm{c}} \pm 0,009$ & $0,371^{\mathrm{b}} \pm 0,005$ & $0,549^{\mathrm{a}} \pm 0,012$ \\
pH & $1,863^{\mathrm{c}} \pm 0,011$ & $2,043^{\mathrm{b}} \pm 0,031$ & $2,107^{\mathrm{a}} \pm 0,021$ \\
TAT (\%) & $0,269^{\mathrm{c}} \pm 0,012$ & $0,481^{\mathrm{b}} \pm 0,024$ & $0,565^{\mathrm{a}} \pm 0,014$ \\
Viskositas (dPa.s) & $0,933^{\mathrm{c}} \pm 0,029$ & $2,077^{\mathrm{b}} \pm 0,087$ & $3,247^{\mathrm{a}} \pm 0,081$ \\
\hline
\end{tabular}

Keterangan: Rerata \pm SD. Huruf di belakang angka rata-rata yang berbeda menunjukkan perbedaan signifikan berdasarkan uji statistik dengan $\alpha=5 \%$ (dalam satu baris yang sama).

Pada Gambar 1 dijelaskan bahwa perubahan kadar gula total menunjukkan penurunan gula total yang makin besar seiring variasi kadar kulit pisang Tanduk yang ditambahkan. Hal ini dapat disebabkan oleh pemanfaatan gula oleh BAL untuk diubah menjadi asam laktat maupun asam-asam organik lainnya (Lactospore, 2000), sedangkan khamir mengubah gula menjadi 
etanol dan $\mathrm{CO}_{2}$ (Madigan, Martinko, Parker, et al., 2003).

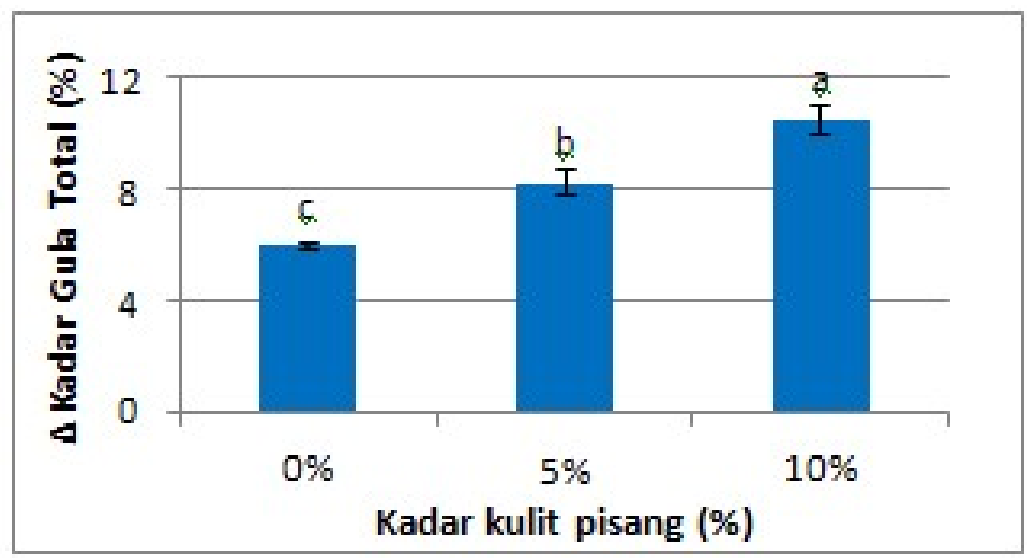

Gambar 1. Perubahan kadar gula total kefir susu nabati dengan berbagai variasi kulit pisang Tanduk.

Berdasarkan Gambar 2, kadar gula reduksi dalam kefir makin banyak dengan adanya kulit pisang Tanduk. Gula reduksi seperti glukosa dan fruktosa merupakan gula sederhana (monosakarida) sehingga lebih mudah dimanfaatkan oleh BAL untuk substrat pertumbuhannya (Chen et al., 1983). Hal ini disebabkan oleh BAL dan khamir yang memerlukan gula sederhana untuk pertumbuhannya diikuti dengan terbentuknya metabolit berupa asam laktat oleh BAL dan etanol oleh khamir (Madigan et al., 2003).

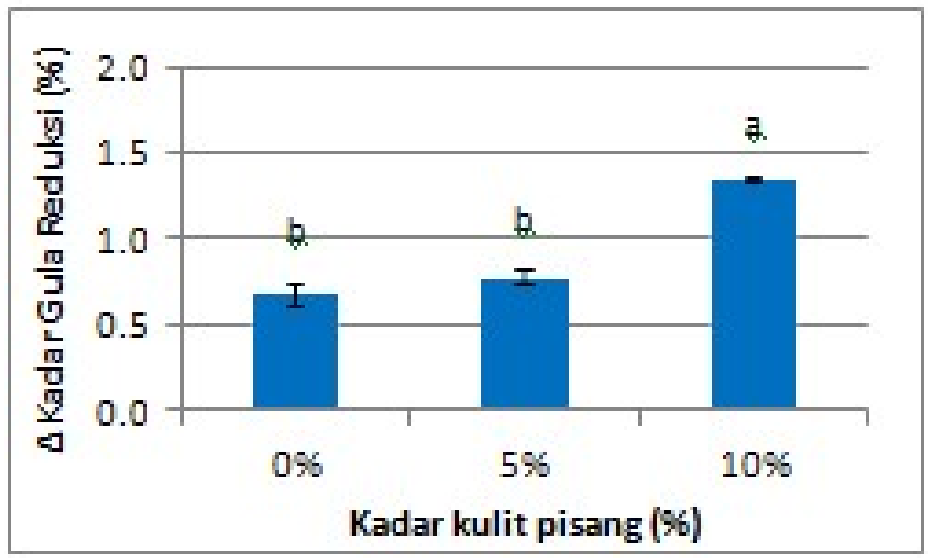

Gambar 1. Perubahan kadar gula total kefir susu nabati dengan berbagai variasi kulit pisang Tanduk.

Berdasarkan Gambar 2, kadar gula reduksi dalam kefir makin banyak dengan adanya kulit pisang Tanduk. Gula reduksi seperti glukosa dan fruktosa merupakan gula sederhana (monosakarida) sehingga lebih mudah dimanfaatkan oleh BAL untuk substrat pertumbuhannya (Chen et al., 1983). Hal ini disebabkan oleh BAL dan khamir yang memerlukan gula sederhana untuk pertumbuhannya diikuti dengan terbentuknya metabolit berupa asam laktat oleh BAL dan etanol oleh khamir (Madigan et al., 2003). 


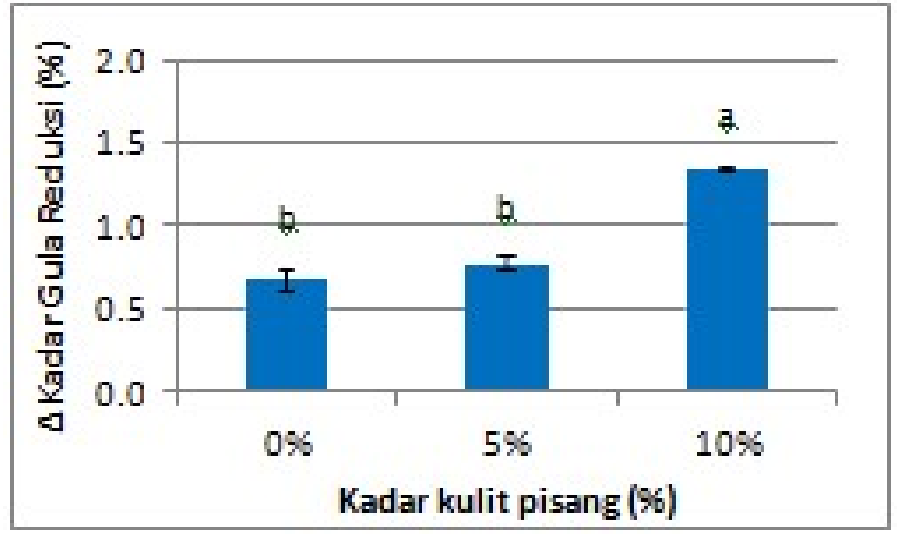

Gambar 2. Perubahan kadar gula reduksi kefir susu nabati dengan berbagai variasi kulit pisang Tanduk.

Pada Gambar 3, kadar asam laktat yang dihasilkan meningkat sesuai dengan makin menurunnya gula total setelah fermentasi (Gambar 1). Peningkatan kadar asam laktat diiringi kadar gula total yang makin menurun sesuai dengan penelitian Rahman (1989). Selain itu, kenaikan kadar asam laktat didukung dengan kenaikan jumlah BAL dalam penelitian ini. Hal ini sesuai dengan pendapat Kurtoğlu dan Yildiz (2011) bahwa kulit pisang berpotensi sebagai prebiotik karena mengandung fructooligosaccharides (FOS) yang mampu merangsang pertumbuhan probiotik. Makin tinggi kadar kulit pisang Tanduk maka makin banyak asam laktat yang dihasilkan diikuti dengan jumlah BAL yang makin banyak. Kadar asam laktat pada kefir susu nabati ini memenuhi kadar asam laktat SNI yogurt $(0,5-2,0 \%)$ yaitu $0,596 \%$ pada penambahan kulit pisang $10 \%$.

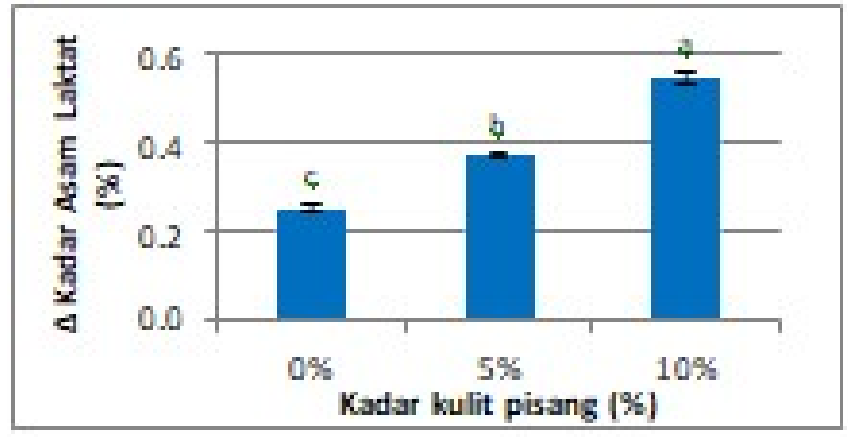

Gambar 3. Perubahan kadar asam laktat kefir susu nabati dengan berbagai variasi kulit pisang Tanduk.

Pada Gambar 4 ditunjukkan bahwa adanya penambahan kulit pisang Tanduk pada kefir susu nabati memberikan peningkatan nilai pH secara signifikan. Berdasarkan hasil uji statistik, pH kefir susu kontrol berbeda signifikan dengan kefir susu yang ditambah kulit pisang Tanduk 5\% dan 10\%. Substrat yang digunakan oleh BAL adalah karbohidrat. Sumber karbon yang dipakai oleh BAL bukan hanya dari gula yang ditambahkan pada pembuatan kefir ini namun juga sukrosa, raffinosa, stakiosa, pati yang terdiri dari amilosa dan amilopektin dalam biji kacang hijau (Kay, 1979) serta 18,5\% karbohidrat dalam 100 gram kulit pisang (Munadjim, 1988). Oleh karena itu, makin banyak substrat yang dapat digunakan bakteri asam laktat untuk menghasilkan asam laktat, maka asam laktat yang terbentuk akan makin banyak. Akumulasi ion $\mathrm{H}^{+}$dari asam laktat yang dihasilkan oleh metabolisme BAL selama fermentasi mengakibatkan penurunan derajat keasaman atau pH (Salminen, Wright, \& Ouwehand, 2004). 
Penurunan $\mathrm{pH}$ yang disertai kenaikan asam laktat dengan adanya penambahan kulit pisang sesuai dengan penelitian Lenny dan Kusnadi (2015).

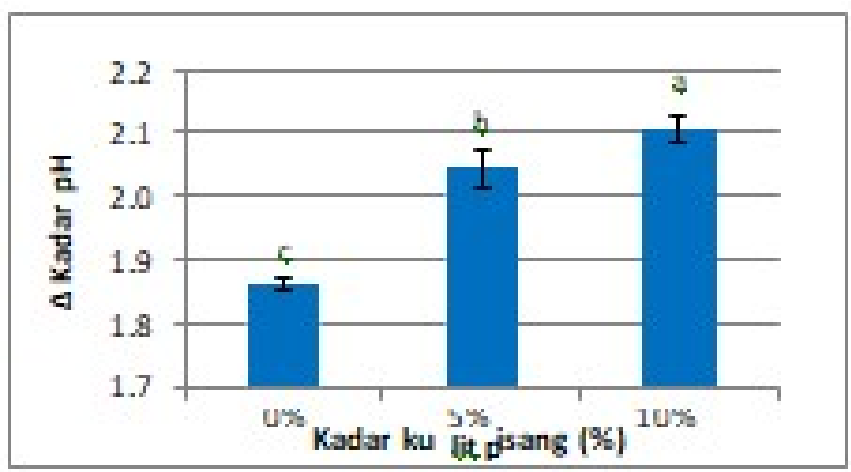

Gambar 4. Perubahan $\mathrm{pH}$ kefir susu nabati dengan berbagai variasi kulit pisang Tanduk.

Pada Gambar 5 ditunjukkan bahwa makin tinggi kadar kulit pisang Tanduk maka makin tinggi juga perubahan TAT pada kefir. Hal ini sesuai dengan peningkatan perubahan $\mathrm{pH}$ yang terjadi. Peningkatan total asam terjadi karena kulit pisang dimanfaatkan oleh BAL sebagai substrat. Asam laktat yang dihasilkan oleh BAL akan terekskresi keluar sel dan akan terakumulasi dalam produk kefir sehingga keasaman akan meningkat (Peter, Mair, Sharpe, \& Holts, 1986).

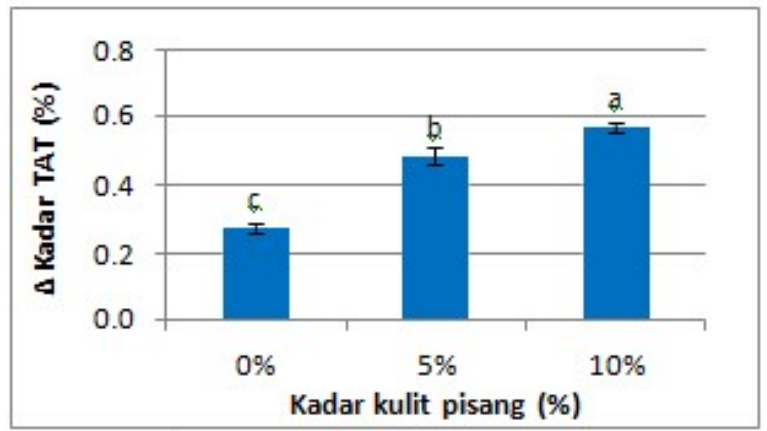

Gambar 5. Perubahan total asam tertitrasi kefir susu nabati dengan berbagai variasi kulit pisang Tanduk.

Kenaikan perubahan viskositas seiring dengan meningkatnya kadar kulit pisang (Gambar 6). Hal ini disebabkan oleh kandungan protein dan asam yang terbentuk juga mempengaruhi peningkatan viskositas. Keberadaan asam yang banyak pada kefir ditandai dengan nilai $\mathrm{pH}$ yang rendah. Asam akan menurunkan kelarutan kasein (protein susu), sehingga terjadi interaksi hidrofobik antara misel kasein membentuk struktur dan konsistensi kefir susu yang menyebabkan produk kefir makin kental (viskositas naik). Makin tinggi kadar protein dan asam dalam produk susu fermentasi maka nilai viskositas makin besar (Tamime \& Deeth, 1980). 


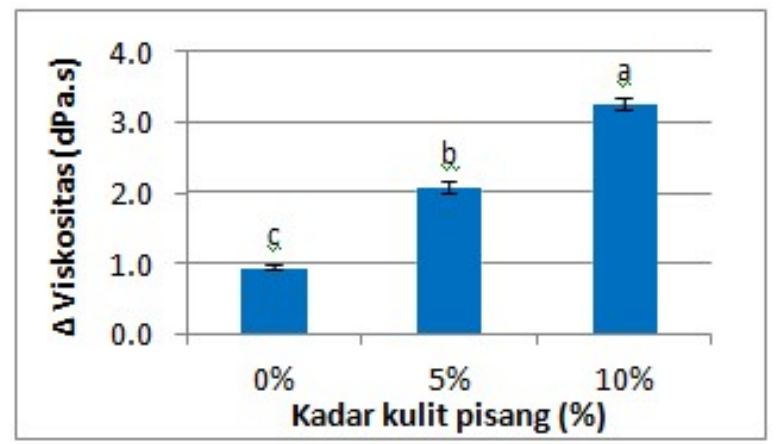

Gambar 6. Perubahan viskositas kefir susu nabati dengan berbagai variasi kulit pisang Tanduk.

\section{Hasil Uji Karateristik Kimia dan Mikrobiologi pada Kefir Susu Nabati dengan Penambahan Kulit Pisang Tanduk Sesudah Fermentasi}

Tabel 2

Data Uji Karakteristik Kefir Susu Nabati Dengan Penambahan Kulit Pisang Tanduk Sesudah Fermentasi

\section{Kadar Kulit Pisang Tanduk (\%)}

\begin{tabular}{lccc}
\multicolumn{1}{c}{ Parameter } & 0 & 5 & 10 \\
\cline { 2 - 4 } & $1,367^{\mathrm{c}} \pm 0,050$ & $1,593^{\mathrm{b}} \pm 0,031$ & $1,847^{\mathrm{a}} \pm 0,0351$ \\
Etanol (\%) & $9,060^{\mathrm{c}} \pm 0,031$ & $9,192^{\mathrm{b}} \pm 0,022$ & $9,339^{\mathrm{a}} \pm 0,054$ \\
$\mathrm{BAL}(\log \mathrm{CFU} / \mathrm{mL})$ & $5,553^{\mathrm{c}} \pm 0,067$ & $5,747^{\mathrm{b}} \pm 0,039$ & $5,900^{\mathrm{a}} \pm 0,045$ \\
\hline Khamir $(\log \mathrm{CFU} / \mathrm{mL})$ & $8,395^{\mathrm{c}} \pm 0,035$ & $8,660^{\mathrm{b}} \pm 0,042$ & $9,105^{\mathrm{a}} \pm 0,078$ \\
Protein $(\%)$ & $2,895^{\mathrm{b}} \pm 0,078$ & $3,030^{\mathrm{b}} \pm 0,141$ & $3,645^{\mathrm{a}} \pm 0,177$ \\
Lemak (\%) &
\end{tabular}

Keterangan: Rerata \pm SD. Huruf di belakang angka rata-rata yang berbeda menunjukkan perbedaan signifikan berdasarkan uji statistik dengan $\alpha=5 \%$ (dalam satu baris yang sama).

Selain bakteri asam laktat yang terdapat pada kefir, ada pula khamir yang dapat mengubah substrat menjadi etanol dan $\mathrm{CO}_{2}$ (Usmiati, 2007). Makin tinggi kadar kulit pisang Tanduk maka makin tinggi juga kadar etanol. Makin banyak substrat yang ada, maka makin banyak etanol yang dihasilkan oleh khamir. Gula dapat difermentasikan dengan cepat oleh khamir, karena mempunyai enzim amilase untuk mengubah gula yang kompleks menjadi gulagula monosakarida (Hidayat, Padaga, \& Suhartini, 2006). Makin banyak substrat atau gula reduksi yang dapat dipecah oleh sel khamir menjadi etanol maka makin tinggi pula kadar etanol yang dihasilkan. Hal ini sesuai dengan penelitian Fratiwi \& Noverita (2008). Peningkatan kadar etanol setelah proses fermentasi dapat dilihat pada Gambar 7. 


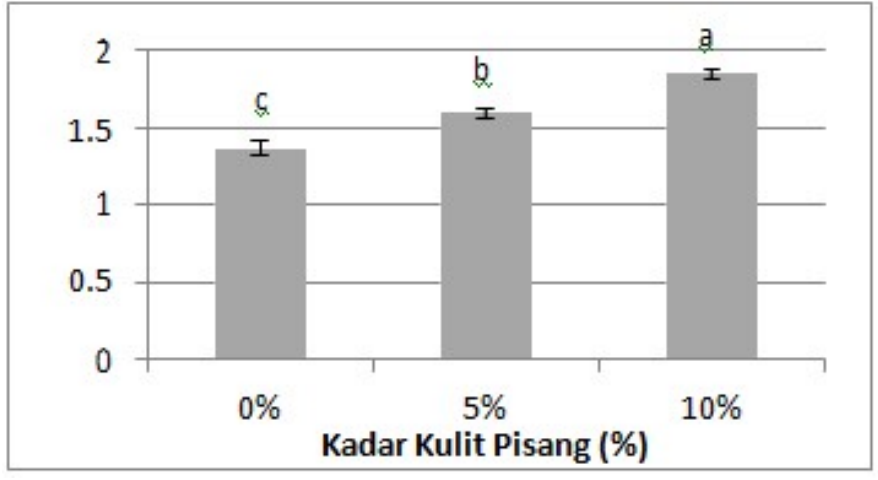

Gambar 7. Kadar etanol kefir susu nabati

dengan berbagai variasi kulit pisang Tanduk

sesudah fermentasi $\left(T_{15}\right)$.

Ada beda signifikan pada jumlah BAL setelah proses fermentasi (Gambar 8). Bakteri asam laktat memanfaatkan gula sebagai sumber energi untuk pertumbuhannya (Prescott, Harley, \& Aklein, 2002). Peningkatan jumlah bakteri asam laktat disertai dengan terbentuknya asam laktat selama proses fermentasi (Chen, McFeeters, \& Fleeming, 1983) serta ketersediaan gula pada substrat yang dapat dimanfaatkan oleh BAL (Widowati \& Misgiyarta, 2003). Hal ini sesuai dengan penelitian Kurtoğlu dan Yildiz (2011) bahwa kulit pisang berpotensi sebagai prebiotik karena mengandung fructooligosaccharides (FOS) yang mampu merangsang pertumbuhan probiotik. Selain itu, jumlah BAL dalam kefir susu dari masing- masing perlakuan telah mencapai standar minimal BAL yaitu $10^{7} \mathrm{cfu} / \mathrm{mL}$.

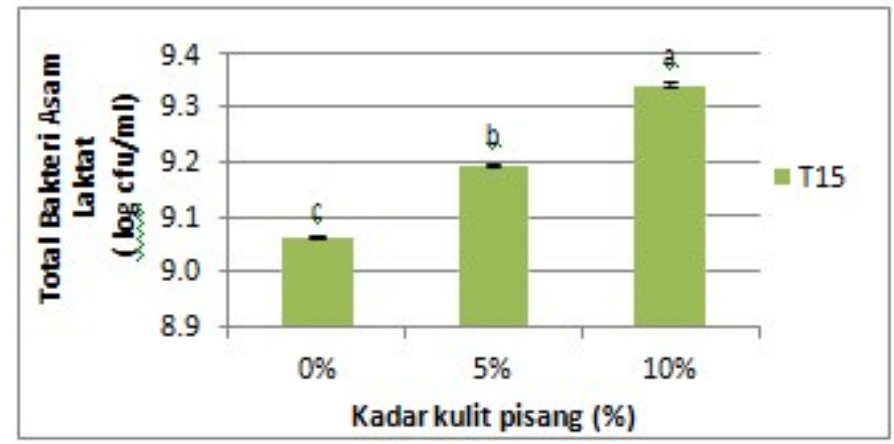

Gambar 8. Jumlah bakteri asam laktat kefir susu nabati dengan berbagai variasi kulit pisang Tanduk sesudah fermentasi $\left(T_{15}\right)$

Pada Gambar 9 ditunjukkan terjadinya peningkatan jumlah khamir pada kefir. Hal ini dikarenakan substrat pada kefir menjadi nutrisi bagi khamir untuk tumbuh. Khamir dapat memecah sukrosa dan gula lainnya untuk pertumbuhan dan menghasilkan produk berupa etanol dan karbondioksida (Madigan et al., 2003). Makin tinggi kadar kulit pisang Tanduk maka jumlah khamir akan makin banyak. Adanya perubahan gula reduksi dan keasaman dalam kefir merupakan refleksi pertumbuhan khamir. Hal ini mungkin terjadi karena adanya hidrolisis glukosida pati oleh amilase dari khamir menjadi monosakarida-monosakarida yang selanjutnya digunakan sebagai sumber karbon utama untuk pertumbuhan sel (Vijayagopal \& Balagopalan, 1988). 


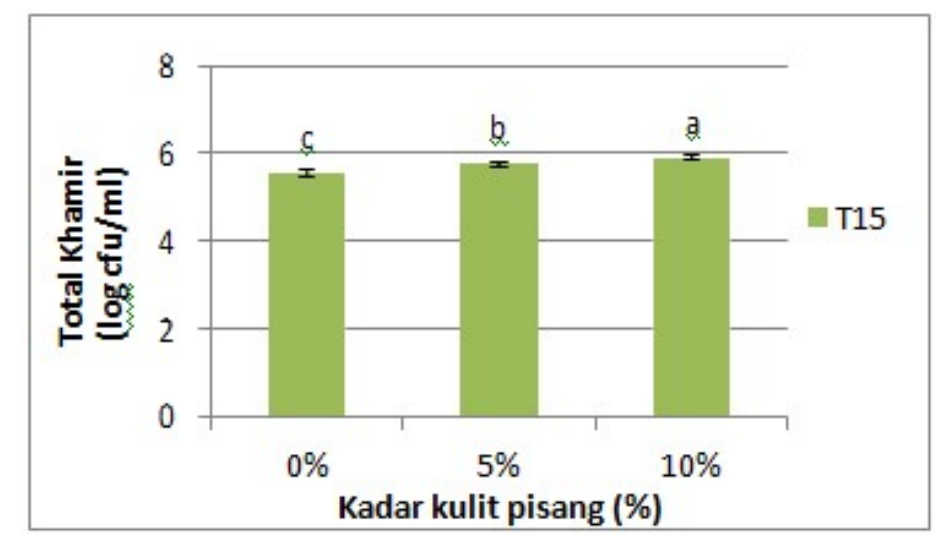

Gambar 9. Jumlah khamir kefir susu nabati dengan berbagai variasi

kulit pisang Tanduk sesudah fermentasi $\left(T_{15}\right)$.

Protein pada penelitian ini sudah memenuhi SNI susu fermentasi (SNI 01- 2981-2009) dan Codex (2003) di mana terdapat protein minimal 2,7\%. Berdasarkan analisis statistik kadar protein pada kefir susu setelah fermentasi, terdapat beda signifikan pada masing-masing perlakuan (Gambar 10). Kandungan protein yang tinggi dapat disebabkan oleh kandungan protein dari substrat yang digunakan serta material protein yang merupakan penyusun mikroba dalam grain kefir. Peningkatan kadar protein yang disertai kenaikan kadar asam laktat, penurunan $\mathrm{pH}$, dan jumlah BAL pada kefir ini sesuai dengan penelitian yang dilakukan Widowati dan Misgiyarta (2003). Susu kacang hijau memiliki protein yang rendah sehingga tidak mencukupi standar dari SNI minuman fermentasi. Oleh karena itu, pada penelitian ini ditambahkan susu bubuk kedelai agar proteinnya memenuhi standar.

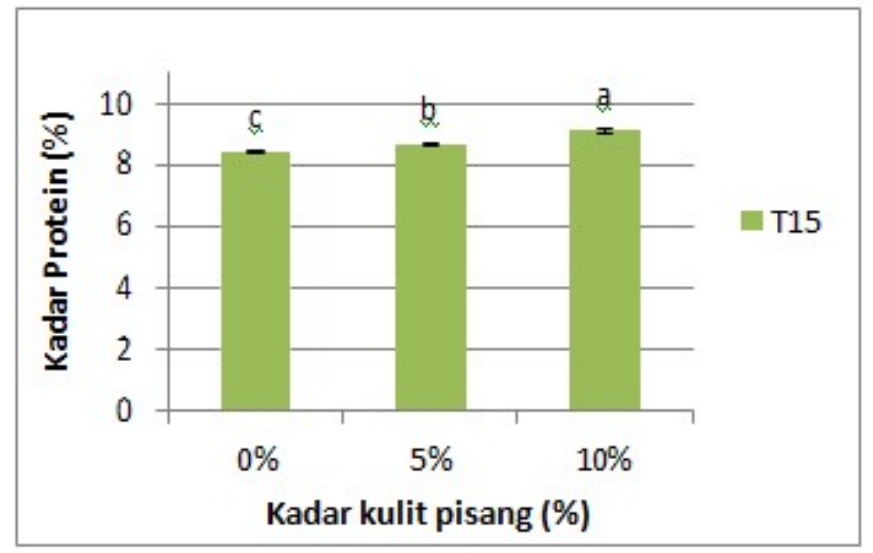

Gambar 10. Kadar protein kefir susu nabati dengan berbagai variasi kulit pisang Tanduk sesudah fermentasi $\left(T_{15}\right)$.

Lemak pada kefir susu nabati dengan ataupun tanpa penambahan kulit pisang Tanduk sudah sesuai dengan Codex (2003), di mana kadar lemak <10\% (Gambar 11). Tingginya kadar protein dan lemak pada kefir akan mempengaruhi tingkat viskositas suatu kefir. Lemak pada susu nabati tergolong rendah sehingga kandungan lemak pada kontrol lebih sedikit dibandingkan lemak pada kefir susu yang ditambah kulit pisang. Berdasarkan hasil uji statistik, terdapat beda signifikan pada kadar lemak masing-masing perlakuan. 


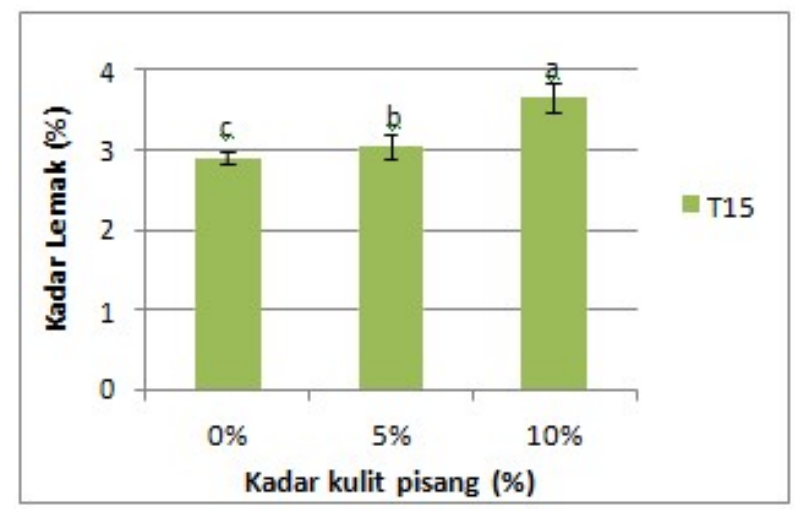

Gambar 11. Kadar lemak kefir susu nabati dengan berbagai variasi kulit pisang Tanduk sesudah fermentasi $\left(T_{15}\right)$.

Uji mikroba kontaminan kefir susu nabati dengan penambahan kulit pisang Tanduk untuk bakteri Coliform dilakukan pada media Lactose Broth (LB) dengan kadar 1× dan 3x kuat. Uji mikroba kontaminan Salmonella sp. dilakukan pada 3 media selektif diferensial, yaitu XLD, $\mathrm{HE}$, dan BSA. Hasil uji bakteri Coliform dan Salmonella sp. kefir susu nabati dengan variasi kulit pisang Tanduk disajikan pada Tabel 3.

\section{Tabel 3}

Hasil Uji Bakteri Coliform dan Salmonella sp. pada Kefir Susu Nabati dengan Penambahan Kulit Pisang Tanduk

\begin{tabular}{|c|c|c|c|c|}
\hline \multicolumn{5}{|c|}{ Coliform } \\
\hline \multirow{2}{*}{$\begin{array}{l}\text { Kadar } \\
\text { Kulit } \\
\text { Pisang (\%) }\end{array}$} & \multicolumn{3}{|c|}{ Tabung yang positif } & \multirow{2}{*}{$\mathrm{APM} / \mathrm{mL}$} \\
\hline & LB $3 \times(10 \mathrm{ml})$ & LB $1 \times(1 \mathrm{~mL})$ & LB $1 \times(0,1 \mathrm{~mL})$ & \\
\hline 0 & 0 & 0 & 0 & $<3$ \\
\hline 5 & 0 & 0 & 0 & $<3$ \\
\hline 10 & 0 & 0 & 0 & $<3$ \\
\hline \multicolumn{5}{|c|}{ Salmonella sp. } \\
\hline \multirow{2}{*}{$\begin{array}{l}\text { Kadar } \\
\text { Kulit } \\
\text { Pisang (\%) }\end{array}$} & & Media & & \multirow{2}{*}{ Hasil } \\
\hline & XLD & $\mathrm{HE}$ & BSA & \\
\hline 0 & Negatif & Negatif & Negatif & Negatif/25 \\
\hline 5 & Negatif & Negatif & Negatif & $\begin{array}{c}\mathrm{g} \\
\text { Negatif/25 }\end{array}$ \\
\hline 10 & Negatif & Negatif & Negatif & $\begin{array}{c}\mathrm{g} \\
\text { Negatif/25 } \\
\mathrm{g}\end{array}$ \\
\hline
\end{tabular}

Berdasarkan data diatas, hasil Angka Paling Memungkinkan (APM) Coliform adalah <3 $\mathrm{APM} / \mathrm{mL}$ dan hasil negatif pada uji kontaminan bakteri Salmonella sp. Hal ini menunjukkan kefir susu nabati dengan penambahan kulit pisang Tanduk yang digunakan untuk uji organoleptik sudah memenuhi standar cemaran Coliform dan Salmonella sp.

\section{Hasil Uji Organoleptik Kefir Susu Nabati Dengan Penambahan Kulit Pisang Tanduk}

Penilaian organoleptik dilakukan dengan uji hedonik scoring untuk mengetahui tingkat kesukaan pada kefir susu nabati dengan variasi kulit pisang Tanduk. Uji hedonik dilakukan 30 orang panelis agak terlatih. Berdasarkan hasil uji organoleptik, tingkat kesukaan panelis 
terhadap aspek rasa, warna, aroma, konsistensi, dan aftertaste pada kefir susu nabati dengan dan tanpa penambahan kulit pisang Tanduk dengan disajikan pada Gambar 12.

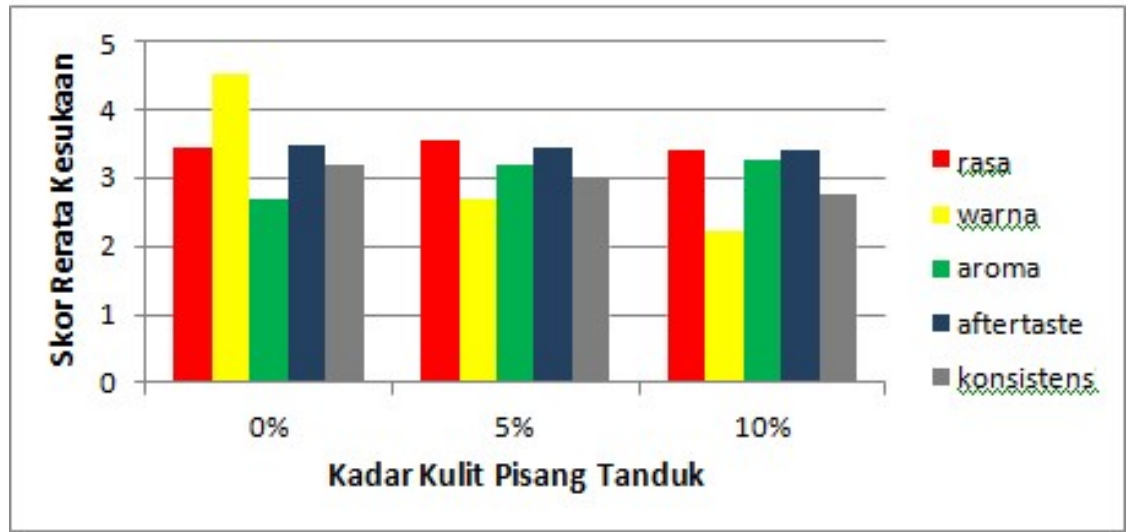

Gambar 12. Tingkat kesukaan rasa, warna, aroma, konsistensi, dan

aftertaste kefir susu nabati dengan variasi kadar kulit pisang Tanduk.

Keterangan: Skor $1=$ Tidak Suka

Skor 2= Kurang Suka

Skor $3=$ Cukup Suka

Skor $4=$ Suka

Skor $5=$ Sangat Suka

Pada Gambar 12, dapat dilihat bahwa secara keseluruhan panelis cukup menyukai rasa dan aftertaste dengan rerata skror \pm 3 , kefir susu dari masing- masing perlakuan. Hal ini dapat disebabkan dari rasa kefir yang memiliki cukup rasa manis dan asam tetapi tidak pahit. Berdasarkan analisis statistik, tidak ada beda signifikan dari masing-masing rasa dan aftertaste pada ketiga perlakuan $\left(P_{\text {value }}>0,05\right)$. Pada Gambar 12 , dapat dilihat bahwa sebagian besar panelis paling menyukai warna kefir susu dengan penambahan kulit pisang Tanduk $0 \%$ dan paling tidak menyukai kefir susu dengan penambahan kulit pisang Tanduk $10 \%$. Selain itu, terdapat beda signifikan $\left(\mathrm{P}_{\text {value }}<0,05\right)$ antara sampel tanpa penambahan kulit pisang Tanduk dengan kefir kadar kulit pisang Tanduk 5\% dan 10\%. Hal ini dikarenakan tingkat kecerahan kefir susu yang makin gelap dengan adanya penambahan kulit pisang sehingga tidak disukai oleh panelis. Pada Gambar 12, panelis lebih menyukai kefir susu dengan penambahan kulit pisang dibandingkan kefir susu tanpa penambahan kulit pisang Tanduk. Hal ini dapat disebabkan oleh aroma pisang yang menutupi aroma langu pada susu nabati. Selain itu, ada beda signifikan antara sampel kefir susu dengan penambahan kulit pisang Tanduk $0 \%$ dengan $10 \%\left(P_{\text {value }}<0,05\right)$. Pada Gambar 12, dapat dilihat bahwa sebagian besar panelis menyukai konsistensi kefir susu dengan maupun tanpa penambahan kulit pisang dan tidak ada beda signifikan diantara masing-masing sampel $\left(P_{\text {value }}>0,05\right)$. Berdasarkan uji hedonik, kefir susu nabati tanpa penambahan kulit pisang Tanduk mendapatkan rerata skor tertinggi, dari aspek warna, konsistensi, dan aftertaste, sehingga dilakukan pengujian deskripsi skala terstruktur dari kefir susu tersebut. Hasil yang didapatkan adalah kefir susu nabati tanpa penambahan kulit pisang Tanduk memiliki rasa yang cukup manis, cukup asam, tidak beralkohol, aroma yang kurang asam, aroma yang cukup langu, berwarna putih kekuningan, menghasilkan aftertaste yang tidak pahit, dan memiliki konsistensi cukup kental. 


\section{Hasil Uji Indeks Efektivitas}

Berdasarkan hasil uji organoleptik, kimia (total asam, protein, dan lemak), dan mikrobiologi (bakteri starter dan total yeast) menggunakan metode indeks efektivitas, perlakuan terbaik pada penelitian ini adalah kefir susu nabati dengan penambahan kulit pisang Tanduk 5\%. Hasil perhitungan perlakuan terbaik disajikan pada Tabel 4.

Tabel 4

Hasil Penentuan Perlakuan Terbaik Menggunakan Metode IndeksEfektivitas

\begin{tabular}{crrrr}
$\begin{array}{c}\text { Kadar } \\
\text { Kulit } \\
\text { Pisang }\end{array}$ & Organoleptik & \multicolumn{1}{c}{$\begin{array}{c}\text { Kimia dan } \\
\text { Mikrobiologi }\end{array}$} & Jumlah & Ranking \\
\hline $0 \%$ & 0,382 & 0 & 0,382 & 3 \\
$5 \%$ & 0,365 & 0,178 & 0,543 & 1 \\
$10 \%$ & 0,12 & 0,4 & 0,52 & 2 \\
\hline
\end{tabular}

\section{SIMPULAN DAN SARAN \\ Simpulan}

Berdasarkan hasil penelitian pembuatan kefir susu nabati dengan penambahan kulit pisang Tanduk, dapat disimpulkan bahwa dalam pembuatan kefir susu nabati dengan penambahan kulit pisang Tanduk, kadar asam laktat, gula reduksi, TAT, dan viskositas makin naik, sedangkan kadar gula total dan pH makin turun. Berdasarkan hasil uji organoleptik, kefir susu nabati tanpa penambahan kulit pisang Tanduk merupakan kefir yang paling disukai dari aspek warna, konsistensi, dan aftertaste. Berdasarkan uji deskripsi skala terstruktur, kefir susu nabati tanpa penambahan kulit pisang Tanduk memiliki rasa yang cukup manis, cukup asam, tidak beralkohol, aroma yang kurang asam, aroma yang cukup langu, berwarna putih kekuningan, aftertaste tidak pahit, dan konsistensi cukup kental. Kefir susu nabati telah memenuhi standar cemaran mikroba sesuai SNI Yogurt 2009 (SNI 01-2981-2009). Perlakuan terbaik dalam penelitian ini adalah kefir susu nabati dengan penambahan kulit pisang Tanduk $5 \%$.

Saran

Berdasarkan hasil penelitian, saran yang dapat diberikan oleh peneliti, yaitu Penelitian lebih lanjut untuk mengetahui umur simpan produk dan meningkatkan daya terima panelis terhadap organoleptik kefir susu nabati dengan penambahan kulit pisang Tanduk serta mengolah keseluruhan kulit pisang Tanduk menjadi tepung untuk dibuat produk pangan selain kefir.

\section{PUSTAKA ACUAN}

Badan Pusat Statistik 2016, Produksi buah-buahan menurut provinsi (Ton), Retrieved from http://www.bps.go.id

Barrangou, R, Altermann, E, Hutkins, R, Cano, R, \& Klaenhammer, TR 2003, 'Functional and comparative genomic analyses of an operon involved in fructooligosaccharide utilization by Lactobacillus acidophilus', Proceeding from National Academy Sciences USA, 100: 8957-8962. 
Chen, KH, McFeeters, F, \& Fleeming, HP 1983, Fermentation characteristic of heterolactic acid bacteria in green juice, Journal Food Science, 48:962- 966.

Codex Alimentarius Commission. 2003, Codex Standard for Fermented Milks: Codex STAN 243. FAO/WHO Food Standards.

DeGarmo, EP, Sullivan, WG, \& Canada, JR 1984, Engineering economics, New York: Macmillan Publishing Company.

Fratiwi, Y, \& Noverita 2008, Fermentasi kefir dari susu kacang- kacangan. VIS VITALIS, 1(2), 4554. Retrieved from http://biologi.unas.ac.id:8080/publikasi/ fermentasi\%20kefir.pdf, Internasional Journal of Food Microbiology, 151(3), 284-288. https://doi.org/10.1016/j.ijfoodmicro.2011.09.016

Hidayat, N, Padaga, MC, \& Suhartini, S (2006). Mikrobiologi industri. Yogyakarta: Penerbit Andi.

Kay, DE 1979, Food legumes, Tropical Product Institute, London.

Kurtoğlu, G, \& Yildiz, S 2011, Extraction of fructooligosaccaride components from banana peels. Gazi University Journal of Science, 24(4): 877-882. Retrieved from http://citeseerx.ist.psu.edu/viewdoc/download?doi=10.1.1.887.5993\&rep=rep1\&typ e=pdf

Lenny, YF, \& Kusnadi, J 2015, Pengaruh penambahan kulit pisang terhadap pertumbuhan bakteri lactobacillus casei pada es krim probiotik, Jurnal Pangan dan Agroindutri, 3(4): 1694-1700.

Madigan MT, J Martinko, J Parker, et al. 2003, Brock biology of microorganisms, 10th ed., Pearson Education, Inc., New York.

Munadjim 1988, Teknologi pengolahan pisang, Jakarta: PT Gramedia.

Peter, S, Mair N, Sharpe ME, \& Holts JG 1986, Bergey's manual of systematic bacteriology, Baltimore: William and Wilkins.

Prescott, LM, JP, Harley, \& D Aklein 2002, Microbiology, Fifth edition, Boston: McGrawHill Companies Inc.

Robinson, D, \& Singh, DN 2001, Alternative protein sources for lying hens, Queensland: Rural Industries Research and Development Corporation.

Salminen, S, Wright, AV, \& Ouwehand, A 2004, Lactic acid bacteria: Microbiology and functional. New York: Marcel Dekker Inc.

Standarisasi Nasional Indonesia (SNI) 2009, SNI 01-2981-2009. Yoghurt, Badan Standardisasi Nasional (BSN), Jakarta.

Tamime, AY, \& Deeth, HC 1980, Production of kefir, koumiss and other related products, In: Tamime, AY (ed.), Fermented milk blackwell science Ltd, Oxford, UK, p.174-216.

Usmiati, S 2007, Kefir, susu fermentasi dengan rasa menyegarkan, Warta Penelitian dan Pengembangan Pertanian 29(2): 12-14. http://pustaka.litbang.pertanian.go.id/ publikasi/wr292078.pdf

Vijayagopal, K, \& Balagopalan, C 1988, Fermentation of cassava starch hydrolysate with immobilized cells of S.cerevisiae, An article, Central Tuber Crops Research Institute (Indian Council of Agricultural Research), Kerala, India.

Wachirasiri, P, Julakarangka, S, \& Wanlapa, S 2009, 'The effects of banana peel preparations on the properties of banana peel dietary fibre concentrate', Songklanakarin Journal of 
Vina, P., et al., Kefir Susu Nabati dengan Penambahan Kulit Pisang Tanduk (Musa Paradisiacal Var. Corniculata),

Science and Technology, 31(6): 605-611. Retrieved from http://rdo.psu.ac.th/sjstweb/journal/31-6/0125- 3395-31-6-605-611.pdf

Widowati, S, \& Misgiyarta, BM 2003, 'Isolasi, identifikasi dan efektifitas bakteri asam laktat lokal untuk fermentasi susu kacang-kacangan', Prosiding Pertemuan IImiah Tahunan Perhimpunan Mikrobiologi Indonesia (PIT-PERMI) 2003, Bandung: IOP.

\section{BIBLIOGRAFI}

Anyasi, TA, Jideani, AIO, \& Mchau, GRA 2014, Effect of organic acid pretreatment on some physical, functional and antioxidant properties of flour obtained from three unripe banana cultivars. Food Chemistry, 172: 515-522. Retrieved from http://dx.doi.org/10.1016/j.foodchem.2014.09.120

Rahman, T, \& Triyono, A 2011, 'Pemanfaatan kacang hijau (Phaseolus radiatus L. ) menjadi susu kental manis kacang hijau, Prosiding SNaPP2011 Sains, Teknologi, dan Kesehatan, Bandung, 2: 223- 230. 